\title{
Korelasi Rasio Neutrofil/Limfosit dengan Handgrip Strenght pada Penyakit Ginjal Kronik Tahap Akhir
}

Sriyani $^{1}$, Muhammad Sulchan ${ }^{2}$, Shofa Chansani $^{2}$

${ }^{1}$ PPDS, Fakultas Kedokteran, Universitas Diponegoro

${ }^{2}$ Staf Pengajar, Fakultas Kedokteran, Universitas Diponegoro

\begin{abstract}
ABSTRAK
Latar Belakang: Pada PGK tahap akhir biasa terjadi melnutrisi energi protein. Inflamasi yang berkelanjutan akan memengaruhi status gizi, massa dan kekuatan otot yang diukur dengan HGS. Salah satu indikator inflamasi adalah rasio neutrofil/ limfosit. Secara teoritik ada hubungan negatif antara rasio nneutrofil/ limfosit dan handgrip strength.

Tujuan: Membuktikan adanya korelasi negatif rasio neutrofil/limfosit dengan HGS padapenyakir ginjalkronik tahap akhir.

Metode Penelitian: Penelitian korelasi ini, dilakukan di unit hemodialisa RSUP Dr, Kariadi Semarangselama bulan November 2016. Subjek 40 orang, ditetapkan dengan metodeconsecutivesampling, diwawancarai dan menjalani pemeriksaan antropometri, HGS, pemeriksaan laboratorium darah. Uji korelasi dilakukan dengan Uji Spearman.

Hasil: NLR normal pada laki- laki 52,5\% dan perempuan 15\%. NLR buruk pada laki-laki $17,5 \%$ dan perempuan $15 \%$. HGS normal pada laki- laki 7,5\% dan rendah $60 \%$. Kategori HGS normal pada perempuan adalah $14 \mathrm{~kg} / \mathrm{f}$ dan $34 \mathrm{~kg} / \mathrm{f}$ dan $24 \mathrm{~kg} / \mathrm{f}$. Uji Spearman menunjukkan tidak ada korelasi antara rasio neutrofil/ limfosit dengan HGS ( $\mathrm{r}=$ 0,27;p:0,08)
\end{abstract}

Kesimpulan: Korelasi negatif antara nilai handgrip strength dan rasio neutrofil/ limfosit tidak dapat dibuktikan

Kata Kunci: rasio neutrofil/ limfosit, HGD, penyakit ginjal kronik. 


\section{PENDAHULUAN}

Penyakit ginjal kronik (PGK) tahap akhir merupakan penyakit yang ditandai dengan adanya penurunan fungsi ginjal pada tahap akhir. Penilaian fungsi ginjal dinilai melalui laju filtrasi glomerulus (LFG), pada PGK berat nilai LFG kurang dari $15 \mathrm{~mL} /$ menit/1.73 $\mathrm{m}^{2}$. Penyakit ginjal kronik tahap akhir memerlukan terapi hemodialisis dan transplantasi ginjal bila terjadi kerusakan berat. Penurunan LFG menyebabkan komplikasi penyakit kardiovaskuler, infeksi, gangguan kognitif dan gangguan fungsi fisik. Progresivitas penurunan fungsi ginjal meningkatkan komplikasi sehingga perlu pencegahan dan tatalaksana pada penyakit ini. ${ }^{1,2}$

Penyakit ginjal kronik tahap akhir berkaitan dengan usia tua, diabetes, hipertensi, obesitas dan penyakit kardiovaskuler. Kasus PGK tahap akhir semakin meningkat berhubungan dengan morbiditas dan mortalitas. ${ }^{1,} 2$ Penyakit ini berdampak negatif pada perekonomian, menghabiskan dana sekitar 24 miliar USD per tahun di negara Amerika. ${ }^{3}$ Prevalensi PGK tahap akhir di dunia diperkirakan sekitar 6-8 \% dari penduduk dunia. ${ }^{-1}$ Insiden dan prevalensi PGK tahap akhir dengan hemodialisis mencapai 200 kasus/juta/tahun pada beberapa negara. Negara Amerika Serikat, Taiwan dan Meksiko mencapai 400 kasus/juta penduduk. Prevalensi di Amerika Serikat mencapai 1800 kasus/juta penduduk, sedangkan di Taiwan mencapai 2400 kasus/juta penduduk. ${ }^{2}$ Prevalensi PGK tahap akhir di Indonesia tahun 2013 paling tinggi pada provinsi Sulawesi Tengah dikuti provinsi Gorontalo, Aceh dan Sulawesi Utara. Daerah Jawa khususnya Jawa Tengah sebanyak $0.3 \% .^{4}$

Peran penting dalam perjalanan perkembangan PGK tahap akhir adalah proses inflamasi. Marker inflamasi yang dapat dilihat yaitu rasio neutrofil/limfosit, sel darah putih, serum $C$-reactive protein, TNF- $\alpha$ dan IL-6. Penelitian oleh Shankar dkk (2011) menunjukkan hasil bahwa adanya hubungan signifikan antara tingkat biomarker inflamasi dengan perubahan LFG pada penderita PGK tahap akhir. ${ }^{8}$ Peran inflamasi dengan menilai jumlah sel darah putih khususnya rasio neutrofil/limfosit sebagai faktor prediksi dan progresivitas pada pasien PGK tahap akhir telah diteliti di Turki tahun $2013 .^{9}$

Gizi kurang yang terjadi pada PGK tahap akhir berupa malnutrisi energi protein. Istilah protein energy wasting (PEW) merupakan malnutrisi yang handgrip strength digunakan pada pasien PGK tahap akhir. Proses tersebut dikarenakan banyak faktor, salah satunya adalah inflamasi. Inflamasi yang berkelanjutan akan mempengaruhi massa dan kekuatan otot, secara langsung memberikan efek negatif bagi status gizi pasien HD berkala. $\frac{10}{}$ Pengukuran kekuatan otot dilakukan menggunakan (HGS) merupakan salah satu indikator untuk menilai gizi kurang. Penelitian oleh Garcia dkk menunjukkan HGS dapat 
digunakan sebagai diagnosis gizi kurang. ${ }^{11}$

Penelitian penggunaan marker inflamasi seperti CRP dan interleukin pada populasi PGK telah banyak dilakukan, sedangkan penggunaan rasio neutrofil/limfosit sebagai penanda inflamasi masih terbatas. Belum ada penelitian mengenai korelasi rasio neutrofil/limfosit dengan HGS pada PGK tahap akhir. Diharapkan dari penelitian ini dapat diketahui korelasi keduanya dan digunakan sebagai dasar untuk penilaian awal kondisi inflamasi dan gizi kurang pada bidang klinik.

\section{METODE PENELITIAN Subyek Penelitian}

Penelitian ini dilakukan di Unit Hemodialisa RSUP dr.Kariadi setelah mendapatkan ethical clearance dari Komisi Etik Penelitian Kedokteran Universitas Diponegoro/RSDK. Penelitian dilakukandari bulan November 2016. Subyek penelitian mengisi informed consent setelah mendapat penjelasan tentang penelitian.Subyek penelitian yang diikut sertakan dalam penelitian adalah pasien yang menjalani hemodialisa rawat jalan di Unit Hemodialisa, yang dipilih menggunakan metode consecutive samplingdengan usia 30-55 tahun, pasien HD rutin 2-3 kali seminggu, selama lebih dari 3 bulan, kesadaran penuh dan bersedia mengikuti penelitian. Subyek akan dieksklusi jika terdapat Amputasi atau luka pada kedua lengan, demam (suhu tubuh lebih dari $37.5^{\circ} \mathrm{C}$ ), penggunaan obat antipiretik, sedang dalam penggunaan obat-obat immunocompromised, penyakit autoimun, keganasan dan penyakit hematologi

\section{Pengukuran Antropometri.}

Pengukuran HGS menilai kekuatan maksimum otot tangan yang diukur dalam satuan $\mathrm{kg}$. Berguna untuk diagnosis kurang gizi melalui penilaian penurunan massa otot. Hasil penilaian penurunan kekuatan otot pada Laki-laki : $\leq$ $28.5 \mathrm{~kg}$; Perempuan $\leq 18 \mathrm{~kg}$.

\section{Pengukuran lain.}

Rasio nutrofil/limfosit menggunakan instrumen hematologi analyzer. Rasio neeutrofil/limfosit merupakan komponen sel darah putih, hasil hitung jenis, yang diukur dalam satuan $\mathrm{mm}^{3}$. Jumlah neutrofil absolut dilakukan pembagian terhadap limfosit absolut. Interpretasi : nilai abnormal : $>3.5$

\section{Analisis Statistik.}

Analisis data meliputi analisis deskriptif dan uji hipotesis. Data tentang karakteristik sampel meliputi usia, jenis kelamin, HGS dan rasio neutrofil/limfosit disajikan secara deskriptif. Masing- masing variabel tergantung dan variabel 
bebas akan dilakukan analisis bivariat. Batas kemaknaan adalah apabila $\mathrm{p} \leq 0,05$ dengan interval kepercayaan 95\%. Analisis dilakukan dengan program SPSS.

\section{HASIL DAN PEMBAHASAN}

Total subyek penelitian adalah 40 orang Berdasarkan jenis kelamin pada sampel penelitian ini tiga perempat jumlah sampel didominasi oleh laki-laki. Subyek berusia antara 30 -55 tahun. Data berdasarkan anamnesis didapatkan jenis komorbid sebanyak 6 jenis, yaitu diabetes, hipertensi, infeksi, batu ginjal, kista ginjal dan dehidrasi. Karakteristik sampel penelitian disajikan dalam tabel 1.

Tabel 1. Karakteristik Subjek Penelitian

\begin{tabular}{llll}
\hline Variabel & Frekuensi & Presentase (\%) & Rerata \pm SD \\
\hline Usia & 40 & & $45,4 \pm 7,27$ \\
\hline Jenis Kelamin & & & \\
Laki- laki & 27 & 67,5 & \\
Perempuan & 13 & 32,5 & \\
\hline Jenis Komorbid & & & \\
Diabetes & 16 & 60 & \\
Hipertensi & 14 & 35 & \\
Infeksi & 4 & 10 & \\
Batuginjal & 3 & 7,5 & \\
Kista ginjal & 2 & 5 & \\
Dehidrasi & 1 & 2,5 & \\
\hline
\end{tabular}

Titik potong nilai HGS normal pada laki-laki >28,5 kg/f dan perempuan > $18 \mathrm{~kg} / \mathrm{f} . \stackrel{10}{ }$ Berdasarkan kategori HGS normal pada laki-laki sebanyak 7,5 \% dan kategori rendah sebanyak $60 \%$. Kategori HGS normal pada perempuan $12,5 \%$ dan HGS rendah sebanyak 20\%. Nilai HGS terendah subyek laki-laki dan perempuan adalah $14 \mathrm{~kg} / \mathrm{f}$ dan tertinggi $34 \mathrm{~kg} / \mathrm{f}$ dan $24 \mathrm{~kg} / \mathrm{f}$. Kategori nilai HGS disajikan dalam tabel 2.

Tabel 2. Nilai HGS Berdasarkan Jenis Kelamin

\begin{tabular}{llllll}
\hline Jenis Kelamin & \multicolumn{2}{l}{ HGS Normal } & \multicolumn{2}{l}{ HGS Rendah } & Median \\
\cline { 2 - 5 } & $\mathrm{f}$ & $\%$ & $\mathrm{~F}$ & $\%$ & ( min- max) \\
\hline Laki- laki & 3 & 7,5 & 24 & 60 & $20(14-34)$ \\
Perempuan & 5 & 12,5 & 8 & 20 & $18(14-24)$ \\
\hline Total & 8 & 20 & 32 & 80 & \\
\hline
\end{tabular}

Nilai rasio neutrofil/limfosit normal $>3,5$, berdasarkan kategori nilai rasio neutrofil/limfosit diperoleh kategori normal pada laki-laki sebanyak 52,5\% dan perempuan $15 \%$. Kategori rasio neutrofil/limfosit buruk pada laki-laki sebanyak 17,5\% dan perempuan $15 \%$. Kategori nilai HGS disajikan dalam tabel 3. 
Tabel 3. Nilai Rasio Neutrofil/ Limfosit berdasarkan Jenis Kelamin

\begin{tabular}{cccccc}
\hline Jenis Kelamin & \multicolumn{2}{c}{ NLR Normal } & \multicolumn{2}{c}{ NLR buruk } & Median \\
\cline { 2 - 5 } & $\mathrm{f}$ & $\%$ & $\mathrm{f}$ & $\%$ & $($ min- max $)$ \\
\hline Laki- laki & 21 & 52,5 & 6 & 15 & $2,6(0,3-5,6)$ \\
Perempuan & 7 & 17,5 & 6 & 15 & $12,3(0,3-4,3)$ \\
\hline Total & 28 & 70 & 12 & 30 & \\
\hline
\end{tabular}

Variabel rasio neutrofil/limfosit dan HGS pada sampel tidak terdistribusi normal sehingga dilakukan uji non parametrik Spearman. Hasil uji Spearman menunjukkan tidak ada korelasi antara rasio neutrofil/limfosit dengan HGS $(\mathrm{r}=0,27, \mathrm{p}=0,08)$.

Penelitian ini menggunakan sampel dengan usia rerata 45 tahun. Jenis komorbid pada sampel penelitian secara berurutan dari yang terbanyak adalah diabetes, hipertensi, infeksi, batu ginjal, kista ginjal dan dehidrasi. Penelitian ini sesuai dengan penelitian oleh Sungjin dkk (2012), bahwa penyakit diabetes dan hipertensi merupakan komorbid terbanyak pada PGK. Kasus PGK akan meningkat sesuai dengan peningkatan penyakit tersebut. Perubahan metabolik pada PGK mendasari komobiditas dan prosedur HD akan memperberat komplikasi malnutrisi. ${ }^{21}$

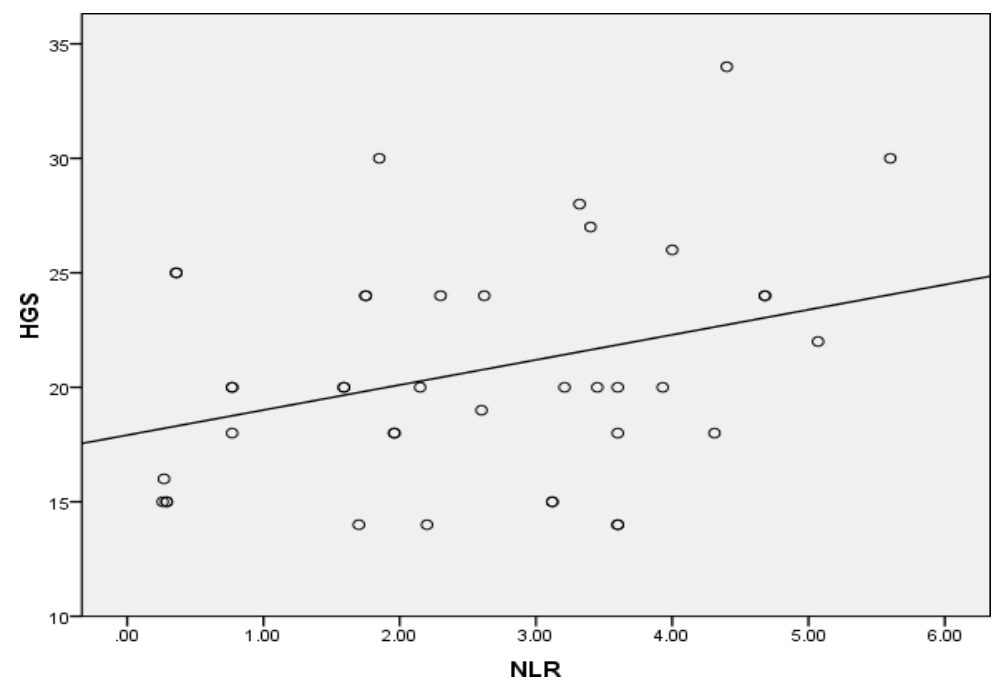

Gambar 1. Scatter Plot Hasil Uji Korelasi antara Rasio Neutrofil/ Limfosit dengan HGS

Sampel laki-laki lebih banyak daripada sampel perempuan. Total sampel 40 dengan jumlah laki-laki 27 dan perempuan 13. Berdasarkan jenis kelamin, median HGS pada laki-laki $20 \mathrm{~kg} / \mathrm{f}$ dan pada perempuan $18 \mathrm{~kg} / \mathrm{f}$. Kategori nilai HGS rendah untuk laki- laki dan perempuan sebanyak 24 subyek dan 8 subyek. Hasil penelitian ini sesuai dengan penelitian sebelumnya ( Sengupta dkk, 2011 ), beberapa faktor yang mempengaruhi nilai HGS adalah jenis kelamin, usia, massa 
tubuh dan tangan dominan. Pengaruh jenis kelamin dimungkinkan karena perbedaan tipe aktivitas diantara keduanya. Laki-laki lebih aktif dibandingkan perempuan dan lebih banyak melakukan pekerjaan fisik. Faktor lainnya adalah perbedaan komposisi tubuh, pada laki-laki memiliki massa otot bebas lemak sekitar $60 \%$, sedangkan pada perempuan memiliki persentase lemak tubuh lebih tinggi. ${ }^{45}$ Penelitian HGS pada pasien HD menyatakan bahwa pengukuran HGS dapat digunakan sebagai alat untuk asesmen lanjutan untuk menilai kekuatan otot dan berhubungan dengan status gizi pasien PGK. ${ }^{10}$

Nilai HGS berperan sebagai penilaian status gizi dengan mengukur kekuatan otot. Nilai HGS dipengaruhi oleh beberapa faktor seperti yaitu usia, jenis kelamin, penyakit komorbid, massa indeks tubuh, riwayat merokok, tingkat pendidikan dan penggunaan tangan dominan dan non dominan. ${ }^{41}$

Rasio neutrofil/limfosit sebagai penanda inflamasi, memegang peran penting pada PGK dengan HD berkala. Hasil penelitian Ismail dkk (2013), menyatakan bahwa rasio neutrofil/limfosit merupakan faktor prediktor progresi pada pasien PGK. Kecepatan progresi lebih rendah pada kelompok pasien dengan rasio neutrofil/limfosit $\geq 3 .{ }^{9}$ Penelitian ini menunjukkan hasil rasio neutrofil/limfosit sebanyak $2 / 3$ jumlah sampel memiliki nilai rasio neutrofil/limfosit normal. Pada 1/3 jumlah sampel nilai rasio neutrofil/limfosit > 3.5. Penelitian oleh Emre dkk (2013) menunjukkan hasil median rasio neutrofil/limfosit adalah 3,48, pada kelompok rasio neutrofil/limfosit lebih tinggi, terdapat serum albumin lebih rendah dan kadar CRP lebih tinggi. Peningkatan kadar neutrofil dan penurunan limfosit berhubungan dengan peningkatan mortalitas pada pasien PGK. ${ }^{32}$

Rasio neutrofil/limfosit dipengaruhi dari nilai absolut neutrofil dan limfosit. Neutrofil sebagai respon imun bawaan dan limfosit sebagai respon imun adaptif. Beberapa faktor yang mempengaruhi adanya neutrofilia dan limfositopenia yang bisa terjadi pada kondisi penggunaan kortikosteroid, kondisi immunocompromised, keganasan, sepsis, trauma, dan penyakit kritis. ${ }^{9}$

Hasil analisis statistik pada penelitian ini menunjukkan bahwa rasio neutrofil/limfosit tidak berkorelasi dengan besarnya nilai HGS ( $r=0,27, p=0,08)$. Penelitian ini tidak membuktikan adanya korelasi antara peningkatan kadar rasio neutrofil/limfosit dengan besar nilai HGS pada subyek PGK dengan HD berkala. Hal ini mungkin disebabkan kurangnya identifikasi faktor perancu. Faktor yang bisa menyebabkan perancu pada hasil NLR yaitu infeksi, penyakit keganasan, penggunaan obat-obatan. Sedangkan faktor yang mempengaruhi nilai HGS adalah jenis kelamin, usia, pekerjaan dan merokok. 


\section{KESIMPULAN}

Simpulan penelitian ini adalah bahwa hubungan negatif antara nilai rasio neutrofil/limfosit dengan hasil pengukuran HGS tidak terbukti. Kelemahan pada penelitian ini perlu dilakukan identifikasi variabel-variabel perancu untuk 2 variabel tersebut.

\section{DAFTAR PUSTAKA}

1. Jha V, Garcia-Garcia G, Iseki K, Li Z, Naicker S, Plattner B et al. Global Kidney Disease : global dimension and perspectives. Lancet 2013; 382: 260-72.

2. .Levey AS, Coresh J. Chronic kidney disease. The Lancet 2012; 379(165-80).

3. Seaghdha CMO, Hwang S-J, Muntner P, Melamed ML, Fox CS. Serum phosphorus predicts incident chronic kidney disease and end- stage renal disease. Journal Nephrology Transplant 2011: 1-6.

4. Badan Penelitian dan Pengembangan Kesehatan Kementerian Kesehatan RI. Riset Kesehatan Dasar 2013: 85-6.

5. Carrero JJ, Stenvinkel P. Inflammation in End-Stage Renal Disease-What Have We Learned in 10 Years? Seminars in Dialysis 2010; 23(5): 498-509.

6. Meuwese CL, Stenvinkel P, Dekker FW, Carrero JJ. Monitoring of inflammation in patients on dialysis: forewarned is forearmed. National Review Nephrology 2011; 7: 166-76.

7. Streja E, Kovesdy CP, Molnar MZ, Norris KC, Greenland S, Nissenson AR et al. Role of Nutritional Status and Inflammation in Higher Survival of African American and Hispanic Hemodialysis Patients. American Journal Kidney 2010; 57(8): 883-93.

8. Shankar A, Sun L, Klein BEK, Lee KE, Muntner P, Nieto FJ et al. Markers of inflammation predict the long-term risk of developing chronic kidney disease:a population-based cohort study. International Society of Nephrology 2011; 80: 1231-8.

9. .Kocyigit I, Eroglu E, Unal A, Sipahioglu MH, Tokgoz B, Oymak O et al. Role of neutrophil/lymphocyte ratio in prediction of disease progression in patients with stage-4 chronic kidney disease. Journal Nephrology 2013; 26(02): 358-65.

10. Leal VO, Mafra D, Fouque D, Anjos LA. Use of handgrip strength in the assessment of the muscle function of chronic kidney disease patients on dialysis: a systematic review. Nephrology Dialysis Transplant Journal 2010: 1-6.

11. Garcia MF, Wazlawik E, Moreno YMF, Führ LM, González-Chica DA. Diagnostic accuracy of handgrip strength in the assessment of malnutrition in hemodialyzed patients. e-SPEN Journal 2013: 181-86.

12. Filiopoulos V, Vlassopoulos D. Inflammatory Syndrome in Chronic Kidney Disease: Pathogenesis and Influence on Outcomes. Inflammation and Allergy-Drug Targets 2009; 8: 369-82.

13. Heng A-E, Cano NJM. A general overview of malnutrition in normal kidney function and in chronic kidney disease. Nephrology Dialysis Transplantation 2009; 3: 118-24.

14. Carrero JJ, Stenvinkel P, Cuppari L, Ikizler TA, Kalantar-Zadeh K, Kaysen G et al. Etiology of the Protein-Energy Wasting Syndrome in Chronic Kidney Disease: 
A Consensus Statement From the International Society of Renal Nutrition and Metabolism (ISRNM). Journal of Renal Nutrition 2013; 23(2): 77-90.

15. Mak RH, Ikizler AT, Kovesdy CP, Raj DS, Stenvinkel P, Kalantar- Zadeh K. Review : Wasting in chronic kidney disease. Journal Cachexia Sarcopenia Muscle 2011; 2: 9-25.

16. Kovesdy CP, George SM, Anderson JE, Kalantar-Zadeh K. Outcome predictability of biomarkers of protein-energy wasting and inflammation in moderate and advanced chronic. The American Journal of Clinical Nutrition 2009; 90: 407-14.

17. Thomas SS, Mitch WE. Mechanisms Stimulating Muscle Wasting in Chronic Kidney Disease: The Roles of the Ubiquitin-Proteasome System and Myostatin. Clin Exp Nephrol Journal 2013; 17(2): 174-82.

18. Slee AD. Exploring Metabolic Dysfunction in Chronic Kidney Disease. Nutrition and Metabolism Journal 2012; 9(36): 1-16.

19. Rattanasompattikul M, Molnar MZ, Zaritsky JJ, Hatamizadeh P, Jing J, Norris KC et al. Association of malnutrition-inflammation complex and responsiveness to erythropoiesis-stimulating agents in long-term hemodialysis patients. Nephrology Dialysis Transplant 2013; 28: 1936-45

20. Anand N, Sitra C, Alam N. The Malnutrition Inflamation Complex Syndrome-The Micsing Factor in the Perio-Chronic Kidney Disease Interlink. Journal of Clinical Diagnostic Research 2013; 7(4): 763-7.

21. Chung S, Koh ES, Shin SJ, Park CW. Malnutrition in patients with chronic kidney disease. Journal of Internal Medicine 2012; 2: 89-99.

22. Tucker PS, Scanlan AT, Dalbo VJ. Review Article Chronic Kidney Disease Influences Multiple Systems: Describing the Relationship between Oxidative Stress, Inflammation, Kidney Damage, and Concomitant Disease. Oxidative Medicine and Cellular Longevity Hindawi Publishing Corporation 2015: 1-8.

23. Dungey M, Hull KL, Smith AC, Burton JO, Bishop NC. Review Article : Inflammatory Factors and Exercise in Chronic Kidney Disease. International Journal of Endocrinology 2013: 1-12.

24. Upadhyay A, Larson MG, Guo C- Y, Vasan RS, Lipinska I, O'Donnell CJ et al. Inflammation, kidney function and albuminuria in the Framingham Offspring cohort. Neprhrology Dialysis Transplantation Journal 2011; 26: 920-6.

25. Zyga S, Kolovos P. Cardiovascular Disease and Chronic Inflammation in End Stage Kidney Disease. International Journal of Caring Sciences 2013; 5(1): 2937.

26. Azab B, Camacho-Rivera M, Taiol E. Average Values and Racial Differences of Neutrophil Lymphocyte Ratio among a Nationally Representative Sample of United States Subjects. PLoS ONE 2014; 9(11): 1-6.

27. Abbas AK, Lichtman AH, Pillai S. Introduction to the Immune System. In: Meritt J, (ed) Basic immunology Functions and Disorders of the Immune System. 4 ed. USA: Elsevier, 2014. pp 1-13.

28. Solak Y, Yilmaz MI, Sonmez A, Saglam M, Cakir E, Unal HU et al. Neutrophil to lymphocyte ratio independently predicts cardiovascular events in patients with chronic kidney disease. Clin Exp Nephrol 2012: 1-9.

29. Azab B, Daoud J, Naeem FB, Nasr R, Ross J, Ghimire P et al. 